\title{
Transforming a traditional commons-based seed system through collaborative networks of farmer seed-cooperatives and public breeding programs: the case of sorghum in Mali
}

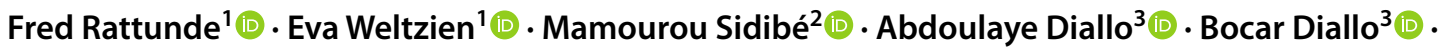 \\ Kirsten vom Brocke ${ }^{4,5}$ (D) $\cdot$ Baloua Nebié ${ }^{2}$ (D) Aboubacar Touré ${ }^{(i D} \cdot$ Yalaly Traoré $^{6} \cdot$ Amadou Sidibé $^{7} \cdot$ Chiaka Diallo $^{8}$. \\ Soriba Diakité ${ }^{9}$ Alhousseïni Bretaudeau ${ }^{10} \cdot$ Anja Christinck $^{11,12}$ (D)
}

Accepted: 6 October 2020 / Published online: 19 October 2020

(c) The Author(s) 2020

\begin{abstract}
Malian farmers' traditional system for managing seed of sorghum, an indigenous crop of vital importance for food security and survival, can be conceptualized as a commons. Although this system maintains a wide range of varieties and helps ensure access to seed, its ability to create and widely disseminate new varieties to meet evolving opportunities and challenges is limited. A network of farmer groups, public breeding programs, and development organizations collaborating in decentralized creation and dissemination of sorghum varieties in Mali is examined regarding (1) how the network developed and what activities it conducts; (2) the resulting varietal diversity, varietal performance and organizational models; and (3) the elements of the traditional seed system that were maintained, strengthened or transformed. A single-case study approach was used that relies on published literature, official catalogues of released varieties and a database of farmer seed-cooperative requests for foundation seed. The functioning of the network and its varietal-, seed-, and organizational- outcomes are documented and the elements of the traditional sorghum seed system that are maintained or strengthened are analyzed. The evolution of the network's reliance on commoning as a social process and its strengthening of core Seed Commons features are discussed with a view to the network's contributions to targeted development outcomes and potential replicability. The case demonstrates how creating a framework for collaboration, enabling actors and organizations to take on collective responsibility while maintaining distributed decision-making at local level, opens opportunities for transforming farming- and food-systems towards sustainability and resilience.
\end{abstract}

Keywords Commons $\cdot$ Commoning $\cdot$ Seed systems $\cdot$ Plant breeding $\cdot$ Farmer cooperatives $\cdot$ Mali

Fred Rattunde

f.rattunde@gmail.com

1 Department of Agronomy, University of Wisconsin, Madison, WI, USA

2 Sorghum Breeding Program, International Crops Research Institute for the Semi-Arid Tropics (ICRISAT), Bamako, Mali

3 Programme Sorgho, Institut D’Économie Rurale (IER), Bamako, Mali

4 Unité Mixte de Recherche (UMR) - Amélioration génétique et adaptation des plantes méditerranéennes et tropicales (AGAP), Centre de coopération Internationale en Recherche Agronomique Pour Le développement (CIRAD), Montpellier, France

5 AGAP, Université de Montpellier, CIRAD, Institut National de Recherche Agronomique (INRA), Montpellier SupAgro, Montpellier, France
6 Union Locale de Producteurs Céréales, Dioila, Mali

7 Unité de Ressources Génétiques, Institut d'Économie Rurale (IER), Bamako, Mali

8 Institut Polytechnique Rurale de Formation et de Recherche Appliquée (IPR/IFRA), Katibougou, Mali

9 Agence Luxembourgeoise pour la Coopération au Développement (LuxDev), Ségou, Mali

10 Laboratoire d'Agro-Physio-génétique et de Biotechnologies Végétales de l'Institut Polytechnique Rural de Formation et de Recherche Appliquée IPR/IFRA, Katibougou, Mali

11 Seed4change Research \& Communication, Gersfeld, Germany

12 German Institute for Tropical and Subtropical Agriculture (DITSL), Witzenhausen, Germany 


\section{Introduction}

In this article, we describe how the farmer-managed seed system for sorghum in Mali can be conceptualized as a commons, and how it has been transformed based on innovations that were co-created by a network of farmer, development and public breeding organizations over a period of two decades.

\section{The traditional sorghum seed system in Mali}

Sorghum is an indigenous staple crop that is deeply embedded in the Malian culture. The ancestors of today's farmers contributed to the domestication of the Guinea-race of sorghum (Harlan and de Wet 1972), the race most widely cultivated in the region today (Weltzien et al. 2018). Onfarm seed saving, selection and storage continue to be widely practiced by farmers in Mali, and knowledge relating to such activities is shared through social interaction, e.g. within families and circles of friends and neighbors (Siart 2008; Coulibaly et al. 2014; Deu et al. 2014).

Cultural norms shape the farmers' collective management of sorghum seed, reflecting their long experience with the crop and its importance for food security. Examples of this can be seen in the frequently expressed notion that "good farmers produce their own seed" (Weltzien et al. 2018). The farmers' own seed is trusted to be adapted to their conditions and needs, while taking seed from 'someone outside' may put their family at risk and results in loss of status and respect (Siart 2008; Christinck et al. 2018). Most farmers thus rely on their own farm-saved seed or, in case of need, access seed from relatives or friends (Siart 2008; Coulibaly et al. 2014).

It is estimated that more than $90-95 \%$ of sorghum seed used in Mali stems from the traditional farmer-managed system, with some variation among regions (Coulibaly et al. 2014; Christinck et al. 2018). The diversity of varieties maintained is high; individual families often maintain 4-5 different varieties, whereas at the village level, ten to 25 or more varieties of sorghum may be cultivated as distinct pure stands in some areas of Mali (Siart 2008).

There is a strong social obligation to share seed with anyone who asks, and being able to provide seed to others involves a gain of status. However, for an individual farmer, it is culturally unacceptable to expect any money in return for seed (Siart 2008; Jones 2017). At most, an equal quantity of grain can be accepted as compensation if the quantity of seed supplied was large. In such cases, grain is often returned after the next harvest, when grain prices tend to be much lower than at the time of sowing. Thus, seed is assigned a high value in the traditional farmer-managed seed system, but the monetary value can be lower than that of ordinary grain (Christinck et al. 2018).

Hence, sorghum seed is not treated by Malian farmers just like any other 'marketable good' (Siart 2008; Coulibaly et al. 2014). Strong cultural barriers to supplying seed on a purely commercial basis are revealed by the negative attitudes to selling seed and to 'bragging' about the quality of one's own seed (Siart 2008).

\section{Conceptualizing seed systems as commons}

According to Bollier (2014), "a commons arises whenever a given community decides to manage a resource collectively, with an accent on fair access, use, and long-term sustainability". Hence, any shared resources that are co-governed by a community of users according to self-determined rules and norms can be a referred to as a commons (Bollier 2014).

Following this broad definition, the traditional system for managing sorghum seed in Mali can be seen as a commons. Malian farmers take responsibility for maintaining seed of a range of varieties, sharing knowledge about seed and varieties with others and collectively ensuring that everyone can access seed based on established rules.

Historically, commons have been categorized based on the type of resource that is managed, such as natural resource commons (Ostrom 1990; 2005), or knowledge and cultural commons (Frischmann et al. 2014). Furthermore, global commons have been defined based on the level of governance, e.g. supranational or global domains (Joyner 2001; Mudiwa 2002). Seed cannot easily be placed in such typologies, since it shares properties of several categories, while also being different in other aspects. ${ }^{1}$

For example, seed can be multiplied if the user community grows; it is thus considered to be generally non-rival in nature (Halewood 2013). Seed shares properties of natural resource commons, knowledge and cultural commons, and global commons (Sievers-Glotzbach et al. 2020). Therefore, conceptions of commons that integrate and transcend different categories are particularly relevant for the study of seed as a commons. Helfrich and Bollier (2019) argue that any commons relies on resources, knowledge and a social process. Wherever people come together to share knowledge and develop rules to address a problem that concerns them, or to manage a resource they depend on, they create a commons. Commons can thus be understood by looking at actors, processes and relationships, rather than focusing on material resources or goods. Euler (2018) therefore considers the social process of 'commoning' to be the core determinant of commons.

\footnotetext{
$\overline{1}$ See also Sievers-Glotzbach and Christinck (this issue).
} 
However, specific processes and rules that are established by a group of commoners are likely to depend, at least partly, on the nature of the material resource in question. For example, Ostrom's 'design principles' of successfully managed commons (Ostrom 2005) have been derived from the study of common pool resources, considering that such resources tend to be threatened by over-use; therefore, some of these principles may not be transferred one by one to the collective governance of seed and varieties.

A recent study of Seed Commons identified four shared features (Sievers-Glotzbach et al. 2020): (1) collective responsibility; (2) protection from private enclosure; (3) collective, polycentric management of seeds and/or varieties; and (4) sharing of knowledge and practical skills relating to breeding, seed management as well as cultivation and use. The concepts of Seed Commons and commoning are used in this article to examine a collaborative network of farmer organizations and public breeding programs.

\section{Challenges and needs for transformation}

Malian farmers, through countless generations, have created and maintained an impressively large range of varieties of sorghum (Lacy et al. 2006; Sagnard et al. 2008; Coulibaly et al. 2008; 2014). By using several varieties, farmers seek the best outcomes under highly variable and unpredictable conditions, and for various production objectives (Lacy et al. 2006). Thus, the farmers' ability to access seed of diverse sorghum varieties with differing adaptive capacities is a critical determinant for productivity and resilience of their farming systems (Lacy et al. 2006; Hausmann et al. 2012; Coulibaly et al. 2014).

Increasing pressure on the land (Coulibaly et al. 2015) and soil nutrient deficiency are severe problems for most Malian sorghum farmers, for men and even worse for women (Leiser et al. 2018). Continued expansion of cropland and reduced fallow periods lead to reduced fodder availability for livestock (De Ridder et al. 2004), fueling conflicts between farmers and transhumant herders (Ollenburger et al. 2016). These developments, along with increasing labor constraints (Weltzien et al. 2006), require modification of farming systems. Furthermore, highly variable rainfall (Lacy et al. 2006; Traore et al. 2013) and alterations of climate make farmers vulnerable to other diverse stresses at unprecedented speed and scale (Jarvis et al. 2010). Low yields and food insecurity are thus central concerns of smallholder farmers in Mali (Ollenburger et al. 2016; Weltzien et al. 2018).

In responding to these challenges, it can be observed that farmers frequently change the sorghum varieties they cultivate (Lacy et al. 2006; Siart 2008) and are actively looking for new varietal options to respond to evolving socio-economic and environmental conditions, challenges and needs (Deu et al. 2014). Although the traditional system offers a great diversity of varieties, the diffusion of new varieties is slow (Weltzien et al. 2006; Coulibaly et al. 2014), with actions generally taking place at a very local scale (Sagnard et al. 2008). Furthermore, strong cultural barriers for requesting or selling seed (Siart 2008; Weltzien et al. 2018) hinder timely and widespread dissemination of new varieties.

Sorghum breeding programs in Mali, both national and international, were established to help meet the described challenges. Yet despite decades of work, farmers' adoption of newly bred sorghum varieties remained limited (Yapi et al. 2000). Moreover, efforts to establish commercial seed distribution systems in West and Central Africa have shown limited success, despite extensive support through subsidy programs and other (often project-based) interventions as well as by introducing legal frameworks that promote such approaches (Djamen 2016).

The changes of the legislative framework have posed new challenges for breeding programs and farmers alike, including legal uncertainties regarding seed transfers among farmers (De Jonge et al. 2019). Mali's seed law of $2010,{ }^{2}$ so as to be in line with the regional seed legislation of the Economic Community of West African States' (ECOWAS), requires certification for the commercial dissemination of seed.

\section{Scope and objectives}

We suggest that the presented case of a collaborative network involving international/national public breeding programs and local farmer organizations could offer a model for governing varieties and seed of food crops as commons, making new varietal options available and accessible to smallholder farmers at large scale and ensuring that the new varieties address their needs.

The objectives of this paper are thus to (1) describe the case of a network of farmer organizations and public sorghum breeders in Mali, its activities and the process by which this network and its activities evolved; (2) examine relevant outcomes of this network, especially relating to properties and performance of co-developed sorghum varieties, varietal diversity, and organizational models; and (3) assess how elements of the traditional commonsbased sorghum seed system in Mali were either maintained, strengthened or transformed in the process of establishing the network.

We discuss these findings with a view to ongoing discourses on developing seed systems and how the concepts of commoning and Seed Commons are embodied in the

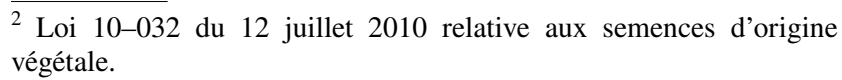


presented case of the sorghum network. Further, we discuss relevant outcomes and replicability of this approach. Finally, we draw conclusions on the potential of the approach for developing seed system in a way that supports the transformation of farming and food systems towards sustainability and resilience.

\section{Methods and data used}

We use a single-case study approach to describe the evolving network of farmer cooperatives and national and international public sorghum breeding programs in Mali (to be denoted here on as the 'sorghum network' or 'network' for brevity). Case studies are used in scientific research to investigate "a real-life phenomenon in-depth and within its environmental context" (Ridder 2017). A single-case study can help to enhance scientific understanding on how and why things happened or evolved in a certain direction (Ridder 2017). Contrary to other approaches, the case is not chosen to represent a larger population, but rather because it is of interest for a specific topic (Stake 2005) or can help to create, advance, test or extend current theories (Eisenhardt and Graebner 2007). It is thus a qualitative approach that typically relies on various sources of data which can be triangulated to result in a more detailed case description (Ridder 2017).

Peer reviewed journal articles, book chapters, books, dissertations and technical reports were produced over the two decades of evolving collaboration. Topics covered include, inter alia, aspects of environmental adaptation, genetic variation for relevant plant traits, methodology and outcomes of the breeding process, traditional seed systems, gender issues as well as new forms of farmer-managed seed production and dissemination. Our case description relies in part on this body of published literature.

Additional information was gained from the official Malian Variety Catalogue and a database curated by the International Crops Research Institute for the Semi-Arid Tropics (ICRISAT) and the Institut d'Economie Rurale (IER) of requests by collaborating farmer cooperatives for foundation seed. The Variety Catalogue, foundation seed database and complementary information provided directly by farmer seed-cooperatives (via e-mail) were used to characterize the diversity of varieties developed by the sorghum network and the spatial and temporal trends of varieties chosen by farmers for production of certified seed. These data present outcomes in terms of varietal diversity and strengthening of farmers' roles as seed system actors.

Lastly, we include information from two unpublished master theses by Miriam Ehret ("Varietal Diversity for Sorghum in the Mandé Region of Southern Mali: Changes from 2004-2009", University of Hohenheim 2010) and
Mamourou Sidibé ("Stratégies Paysannes pour Développer la Vente de Semences Certifiées des Variétés et Hybrides de Sorgho au Mali. Cas de l'Union Locale des Producteurs de Céréales (ULPC) dans le Cercle de Dioila", Centre de Formation et d'Appui Conseil pour le Développement Local (Delta-C) 2018) on strengths, weaknesses and strategies of farmer organizations engaged in distributing certified seed.

The methodology for obtaining and evaluating empirical data is described in the respective publications. In this article, we use both qualitative and quantitative data from the specified sources without further evaluation. Data from the foundation seed database were analyzed using simple spreadsheet functions to assess the seed-request patterns over time and regions. Detailed information regarding the collaborating farmer seed-cooperatives was provided by their representatives and by ICRISAT.

\section{Results}

In this section, the network of farmer cooperatives and public breeding programs that evolved to address the identified challenges is briefly described, followed by a presentation of varietal and organizational outcomes. A third section summarizes how elements of the traditional farmer-managed seed system were maintained or transformed as the network evolved.

\section{The development of the sorghum network in Mali}

Following internal and external reviews and assessments, a complete re-orientation of the joint breeding activities was initiated in 1998 by a group of sorghum breeders from ICRISAT and IER. Both institutes are publicly funded research organizations.

One key element of the new approach was the development of partnerships with existing farmer organizations, mostly farmer-managed cooperatives engaging in collective marketing of grain. Development organizations and extension services were also involved, both informally and as partners in specific projects.

The first farmer organizations engaged in collaborative sorghum activities were Union Locale de Producteurs de Céréales (ULPC), a union of 43 cooperatives that facilitates grain commercialization, and the Association des Organisations Professionelles Paysannes (AOPP), representing Malian farmer organizations (Weltzien et al. 2006), both operating in the Koulikoro region of southern Mali. The sorghum network expanded its activities as it accumulated organizational learning, other cereal producer cooperatives wished to collaborate, and new joint projects permitted upscaling to the Sikasso and Mopti regions. The network activities thus grew to cover the three major sorghum 


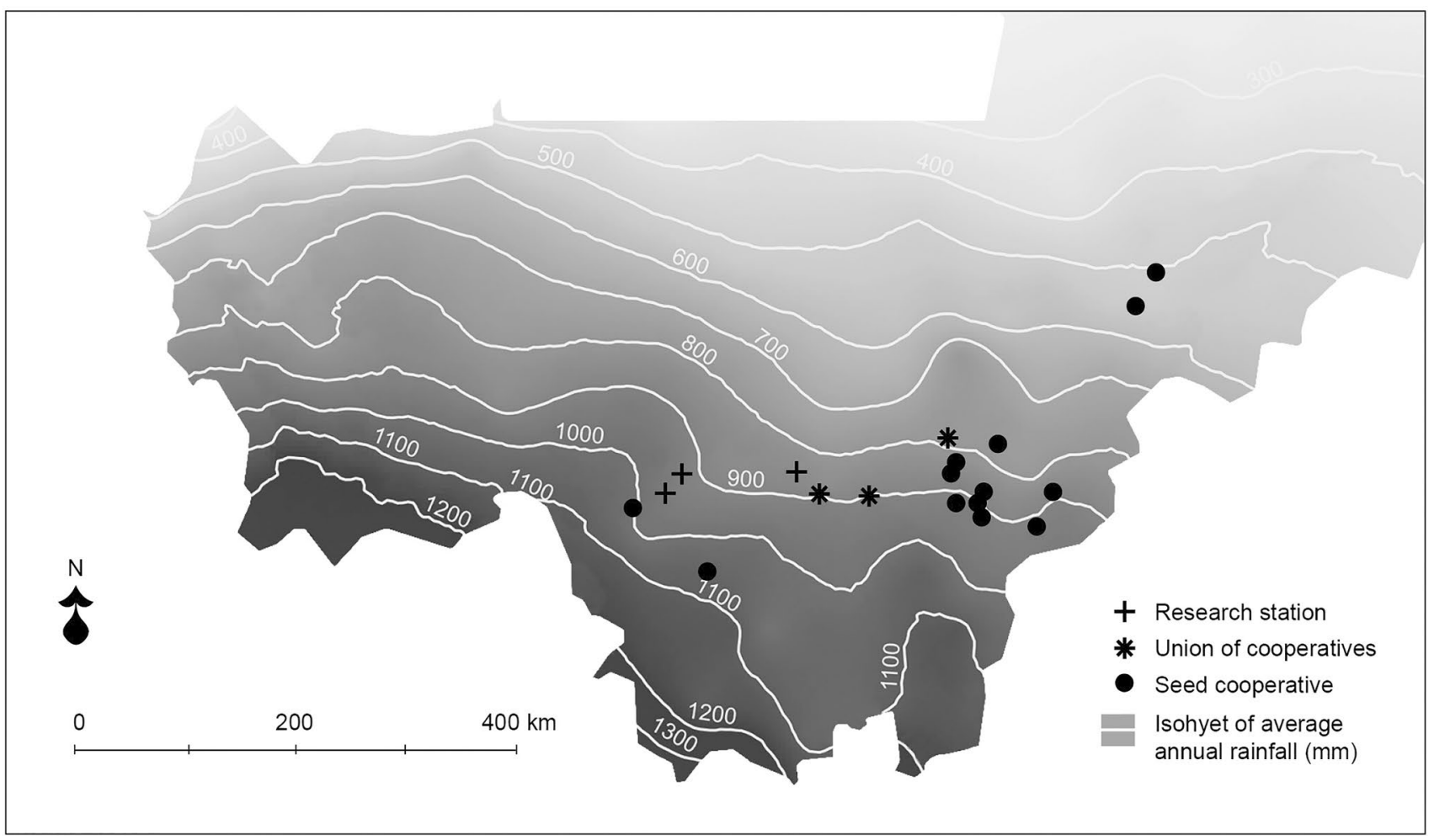

Fig. 1 Map of southern Mali showing locations of individual farmer seed-cooperatives, unions of cooperatives and research stations collaborating in the sorghum network with overlay of average annual rainfall isohyets; map created with QGIS 3.6 using climate data from

production zones of Mali (Christinck et al. 2014) over a wide range of rainfall conditions (Fig. 1).

ICRISAT and IER negotiated 'Memoranda of Understanding' (MoU) with farmer organizations as frameworks for stating common goals and modes of operation. The MoUs also indicated that specific project-based agreements would be developed regarding transfer of funds, accountability and communication (Weltzien et al. 2006).

Initially, the work focused on observing, understanding and exploring farmers' own practices of seed selection and management, current and desired varietal options, production objectives and emerging issues regarding sorghum production (Weltzien et al. 2006). Interactions took place through various on-farm and on-station participatory breeding activities (Weltzien et al. 2020). Farmers also explored the sorghum diversity available with breeders by visiting research stations or on-farm plots (Diakite 2003; Siart 2008) and identified and prioritized preferred traits for future improvements (Weltzien et al. 2006; 2008; Diallo et al. 2018).

Targeted studies of specific topics, such as farmers' seed systems and trait preferences (Diakité 2003; Siart 2008; Ehret 2010, unpublished work; Deu et al. 2014; Diallo et al. 2018), as well as women's role in sorghum production and https://www.worldclim.org/data/worldclim21.html (Fick and Hijmans 2017) and geographic coordinates provided by IER and ICRISATMali

use (Isaacs et al. 2018; Rattunde et al. 2018) were undertaken. Also, characterizations of agro-ecological and climatic factors influencing crop-production and crop improvement research (Abdulai et al. 2012; Herrmann et al. 2013) were conducted.

The insights gained through consultations with farmers and directed studies informed the breeders regarding farmers' preferences and key issues regarding sorghum production (Weltzien et al. 2006). Priority setting for the sorghum network was thus a dynamic process based on continual learning (Weltzien et al. 2020). The priority setting involved determination of priority traits, identification of germplasm base, and choice of the type of varieties (e.g. open-pollinated (OPV) or hybrid) to be bred (Weltzien and Christinck 2017).

On-farm variety trials rapidly became a major area of collaboration based on farmers' keen interest to see new varieties with novel traits and trait combinations. A twostage variety testing scheme evolved for joint evaluations of diverse new breeding materials (Weltzien et al. 2006; 2008; Weltzien and Christinck 2017). The initial Stage-1 trials (so called '32 Entry Trials') involved village-level evaluations of priority traits chosen by the farmers and overall varietal appreciation (Weltzien et al. 2008), replicated yield 
measurements, as well as grain qualities through postharvest culinary testing (Isaacs et al. 2018). The Stage-2 'Adaptation Trials' were conducted by both men and women farmers in up to 60 villages with fewer entries, often chosen by village-level farmer groups (Weltzien et al. 2006; 2020). Activities to generate new diversity and create experimental varieties were also conducted (Rattunde et al. 2016; Weltzien et al. 2020).

Farmers' demand for the Adaptation Trials soon surpassed the breeders' capacity to prepare these trial sets. Farmers' interest in these trials appeared to be partly due to the opportunity of obtaining small quantities of seed of experimental varieties for further multiplication. Farmer cooperatives thus started exploring options to produce seed for wider distribution (Dalohoun et al. 2011). Farmers opted to produce certified seed as it would provide official recognition for the quality of their work and enable selling seed to emerging seed trade companies and non-governmental organizations (NGOs) in view of expected seed legislation changes. Training and support provided by public breeders and national seed specialists (Weltzien et al. 2020) enabled several farmer groups to launch production of certified seed of preferred sorghum varieties identified in the trials. One of these groups, the Coopérative pour la Promotion de la Filière Semence de Mandé (COPROSEM), emerged directly from farmer-testers engaged in the network for variety evaluations (Dalohoun et al. 2011).

The total amounts of sorghum seed produced by the farmer cooperatives in Mali were initially very small but increased steadily over the years (Christinck et al. 2014) and extended to other crops such as maize, groundnut and rice (Dalohoun et al. 2011; Christinck et al. 2014). Although the tonnage of seed sold by the cooperatives to emerging seed companies increased over time, no measurable seed sales occurred in the vicinity of the farmer seed-cooperatives, with most seed being distributed by NGO or government programs, and retail sales limited to shops in urban and periurban areas (Dalohoun et al. 2011; Christinck et al. 2014; 2018). Furthermore, the farmer seed-cooperatives struggled under the unreliable purchases by seed companies, who only obtained seed once receiving orders, and late payments, often after the cultivation season had already started (Christinck et al. 2014).

The seed producer cooperatives thus sought options to increase seed sales directly to farmers that would offer a more predictable and sustainable market, serve local farmers' needs, and overcome farmers' limited experience and cultural barriers to seed purchase (Sidibé 2018, unpublished work). They tested communication and experiential approaches that included sale of 'mini-packs' of $100 \mathrm{~g}$ for 'sampling' new varieties, decentralized seed conditioning and packaging by cooperative members to increase trust and transparency, rural radio broadcasts at harvest events of village-level variety comparisons, and testimonials by respected farmers (Weltzien et al. 2020). They further experimented with diverse distribution pathways such as seed fairs, stands and mobile selling at weekly markets (Dalohoun 2011; Christinck et al. 2014; Sidibé 2018, unpublished work).

An assessment conducted in 2014 found that the sorghum network's collaborative activities had evolved over three phases: (1) engagement solely in participatory breeding; (2) establishing the production of certified seed; and (3) linking seed production activities with seed marketing and dissemination targeting farmers in nearby areas (Christinck et al. 2014).

\section{Varietal and organizational outcomes}

\section{Properties and performance of co-developed varieties}

The new varieties co-developed by the network range from extremely short-cycle (90 days) to long-cycle ( $140+$ days $)$ growth durations suited for the diverse production systems and conditions in Mali (CILSS, 2016). The varieties also differ for height, from tall $(4 \mathrm{~m})$ to short (less than $2 \mathrm{~m}$ ), and for the panicle form, from lax and drooping to erect (CILSS 2016).

The tall varieties with drooping panicles are like the farmers' local varieties whereas the shorter varieties represent a novel plant type with stems that are less woody and of higher quality for livestock fodder than those of tall varieties (Weltzien et al. 2018). Whereas the farmers' local varieties are cultivated primarily for food-grain production (Weltzien et al. 2018), these shorter 'dual-purpose' varieties are cultivated to produce both grain for human consumption and stover for feeding livestock (Deu et al. 2014). Some of the newest varieties combine good quality grain for food and stems that are sweet and juicy. These 'multi-purpose type' varieties can be used for production of grain, fodder for livestock and sorghum syrup, thus differing considerably from the farmers' local sweet-stemmed sorghums that have poor grain quality and are not used for food.

Certain varieties were identified as having superior adaptation to phosphorous (P)-deficient soils (Leiser et al. 2012), which are prevalent in both men's but especially in women's sorghum production fields in Mali (Leiser et al. 2018). These varieties exhibited superior $\mathrm{P}$ uptake and/or P-use efficiency capacities and included both traditional and new plant types (Leiser et al. 2014).

Improving the grain-yielding ability of new varieties was a key objective of the sorghum network (Weltzien et al. 2020). The newly bred OPV and hybrid varieties, chosen by farmers to compare with their own varieties in their own fields, showed both yield and economic net-return superiorities over the local varieties (Table 1). Furthermore, 
Table 1 Grain yield and economic net-return superiorities of openpollinated (OPV) and hybrid-varieties relative to the farmers' own local varieties under the farmers'- and intensified-agronomic practices across 81 farmer-managed Adaptation Trials in Mali between 2009 and 2012 (summarized from Weltzien et al. 2018)

\begin{tabular}{llllll}
\hline Variety type & \multicolumn{2}{l}{ Farmer practice } & & \multicolumn{2}{l}{ Intensified practice } \\
\cline { 2 - 3 } \cline { 5 - 6 } \cline { 5 - 6 } & Yield \% & Net-return \% & & Yield \% & Net-return \% \\
\hline OPV & 14.6 & 14.2 & 25.4 & 31.4 \\
Hybrid & 30.4 & 28.4 & & 42.7 & 52.1 \\
\hline
\end{tabular}

Table 2 The number of on-farm comparisons, hybrid and local-variety mean yields and hybrid yield superiorities in side-by-side 0.25 ha plots of three new sorghum hybrids and the farmer's own local varieties organized by the Compagnie Malienne pour le Développement du Textile (CMDT) in 2014 in the Koutiala and Sikasso regions of Mali (data provided by CMDT and ICRISAT-Mali)

\begin{tabular}{lllll}
\hline Hybrid Variety & $\begin{array}{l}\text { Number on-farm } \\
\text { comparisons }\end{array}$ & Yield $\left(\mathrm{kg} \mathrm{ha}^{-1}\right)$ & $\begin{array}{l}\% \text { Hybrid } \\
\text { Superior- } \\
\text { ity }\end{array}$ \\
\cline { 3 - 4 } & & Hybrid & Local & \\
\hline Pablo & 60 & 1236 & 876 & 41 \\
Fadda & 58 & 1084 & 768 & 41 \\
Sewa & 42 & 1056 & 780 & 35 \\
Total & 160 & 1136 & 812 & 40 \\
\hline
\end{tabular}

considerable mean yield- and net-return superiorities were exhibited under the farmers' traditional agronomic management as well as improved management practices by both the new OPV and hybrid varieties. The yield superiorities of the new hybrids over the farmers' local varieties did not differ discernably between women's and men's field comparisons across the series of Adaptation Trials between 2009 and 2012 (Krista Isaacs, in preparation).

Large (35 to 40\%) hybrid yield superiorities over local varieties were shown by short- and intermediate-height hybrids across all productivity conditions (Rattunde et al. 2013) and by a tall Guinea landrace-based hybrid in the lowest yielding environments (Kante et al. 2017) in the network's Stage-1 on-farm yield trials. Similar hybrid yield superiorities were also observed in farmer's side-by-side comparisons with their own variety in large ( $0.25 \mathrm{ha})$ field plots (Table 2). Village level surveys revealed how the cultivation of these new sorghum hybrids was associated with large yield increases, reduced purchases of sorghum for food and increased portions of harvest sold as grain (Smale et al. 2018).

An important feature of the landrace-based hybrids coproduced by the network is their ability to retain yield superiority over local varieties when sowing second-generation (F2) seed. Both multi-year on-station trials (Frey et al. in prep.) and feedback from many farmers indicate that the hybrid 'Pablo' had no observable yield loss when using F2 seed, and some farmers report that even the third-generation seed does not result in yield losses. For the hybrid 'Fadda', grain yield tends to decrease when F2 seed is used but it is still superior to that of the local varieties (M. Sidibé, personal communication).

\section{Varietal diversity}

Farmer seed-cooperatives in the network produced seed of 28 sorghum varieties over the last four years (Table 3). Only seven of these varieties were developed prior to the collaborative activities and 21 were newly co-created by the network and registered in 2008 or more recently (Table 3 ). The new varieties include 13 open-pollinated varieties (OPV), five hybrid varieties, and three female hybrid seed-parents (Table 3).

The new varieties created by the network have diverse genetic backgrounds, ranging from pure Guinea-race to partial Guinea-race with varying degrees of introgressed Caudatum-race germplasm that comes from more Eastern and Central Africa (Harlan and de Wet 1972). The varieties include direct selections out of local landrace varieties, like 'Tieblé' (pure Guinea-race), to varieties that are predominantly Guinea-race with introgression of a small (e.g. 15\%) amount of Caudatum-race (e.g. the variety 'Lata', Weltzien et al. 2018), to inter-racial varieties that are derived from crossing and backcrossing between Guinea- and Caudatummaterials (like 'Tiandougoucoura').

Seed production by farmer cooperatives, mostly organized at the community level, demonstrates area-specific choices of varieties. The novel dual- and multi-purpose plant-type OPV varieties represented a much larger (nearly half) proportion of varieties chosen for seed produced in the Dioila and Koutiala zones (Table 4), where livestock populations and demand for fodder are higher (Weltzien et al. 2018). The traditional OPV varieties represented one third of the varieties produced by cooperatives in the Mandé and Dioila zones, whereas they constituted only around $12 \%$ of the varieties produced in Koutiala, where more intensified farming is practiced (Rattunde et al. 2016).

Among the traditional type OPV varieties, farmers emphasized seed production of varieties with novel traits such as extra-early maturity for breaking the 'hungry season' or enabling later sowing (Dalohoun et al. 2011) or adaptation to altered rainfall patterns (vom Brocke et al. 2014). Some landrace-derived varieties with maturity and plant type similar to the farmers' local varieties were also widely appreciated (e.g. 'Tieble' and 'Boboje') and regularly included in seed production (Table 3).

The varieties that farmers chose for seed production were, on average, quite new with half or more of the varieties 
Table 3 Sorghum varieties in certified seed production by farmer-cooperatives, classified by the type of variety, racial background, year of registration, and the number of villages in which each was produced by year (data from the Foundation Seed Request Database, ICRISAT-Mali)

\begin{tabular}{|c|c|c|c|c|c|c|c|c|}
\hline Variety & Type $^{\mathrm{a}}$ & Race $^{\mathrm{b}}$ & Reg & 2011 & 2016 & 2017 & 2018 & 2019 \\
\hline Jacunbe & Trad- OPV & G & 1987 & 3 & 8 & 8 & 4 & 4 \\
\hline Segounioni & & G & 1997 & & 1 & & & \\
\hline Tieble & & G & 2001 & 10 & 6 & 5 & 5 & 2 \\
\hline Soumalemba & & G & 2001 & 3 & 1 & & & \\
\hline N'golofing & & $\mathrm{G}$ & 2002 & 1 & & & & \\
\hline Bobodje & & G & 2008 & 6 & 7 & 3 & 3 & 2 \\
\hline Douaje & & G & 2010 & 4 & 2 & & 1 & 1 \\
\hline Diema & & G & 2010 & & 1 & 1 & 2 & \\
\hline Gnosikoni & & G & 2012 & & 2 & 4 & 4 & 3 \\
\hline Seguifa & DP- OPV & IR & 1993 & 2 & & 1 & 1 & 1 \\
\hline Niatchiama & & IR & 1997 & 1 & & & & \\
\hline Soumba & & IR & 2001 & 3 & 1 & 1 & 3 & \\
\hline Grinkan & & IR & 2007 & 2 & 2 & 2 & 3 & 1 \\
\hline Lata & & G & 2009 & 3 & & & 1 & \\
\hline Tiandougoucoura & & IR & 2010 & & 2 & 5 & 9 & 9 \\
\hline Pekê & & IR & 2015 & & & & & 1 \\
\hline Samboni & & G & 2015 & & 2 & & 1 & 1 \\
\hline Mamba & & IR & 2020 & & & & & 1 \\
\hline Jigikala & MPS-OPV & IR & 2015 & & 1 & 2 & 3 & 2 \\
\hline Kalawassa & & IR & 2015 & & 1 & & & \\
\hline Soubatimi & & IR & 2015 & & & 13 & 11 & 11 \\
\hline Tiokala & & IR & 2015 & & 3 & 3 & 3 & 2 \\
\hline FambeA & Hyb-female & G & 2009 & & 4 & 4 & 2 & 1 \\
\hline 02-SB-F5DT-12A & & IR & 2015 & & 2 & 2 & 2 & 2 \\
\hline 97-SB-F5DT-150A & & IR & 2009 & & 1 & & & \\
\hline Pablo & Trad-Hyb & G & 2012 & 8 & 18 & 19 & 20 & 23 \\
\hline Niakafa & & G & 2012 & 2 & 1 & 1 & 1 & \\
\hline Sewa & DP-Hyb & IR & 2008 & 1 & 5 & 6 & & 2 \\
\hline Fadda & & G & 2008 & 9 & 11 & 7 & 9 & 9 \\
\hline Grinkan Yerewolo & & IR & 2011 & & 4 & 3 & & \\
\hline
\end{tabular}

${ }^{a}$ Trad-, DP and MPS denote tall traditional, shorter dual-purpose and multi-purpose sweet stem plant types, respectively; OPV, Hyb-female and Hyb denote open-pollinated variety, hybrid female seed-parent, and hybrid variety, respectively

${ }^{\mathrm{b}} \mathrm{G}$ and IR denote Guinea-race and Guinea-Caudatum inter-racial genetic backgrounds, respectively
Table 4 Number of varieties that network farmer-cooperatives chose for seed production between 2016 and 2019 in the Mande, Dioila and Koutiala zones of Mali, differentiated by type of variety and the total over all types (data from Foundation Seed Request Database, ICRISAT-Mali)

\begin{tabular}{llll}
\hline Variety type & Mande & Dioila & Koutiala \\
\hline OPV (Traditional) & 3 & 7 & 2 \\
OPV (Dual- and multi-purpose) & 2 & 10 & 7 \\
Hybrid Female-Parent & 1 & 2 & 3 \\
Hybrid & 4 & 5 & 4 \\
Total & 10 & 24 & 16 \\
\hline
\end{tabular}

registered in 2010 or later (Table 3). Seed of two or three new varieties was produced each year. A total of nine new varieties were chosen by farmer cooperatives for seed production in 2016 that had not been produced five years earlier (Table 3). The types of varieties chosen for seed production also shifted over time. Whereas more villages produced traditional-type varieties in 2011 and 2016, seed production of varieties with new plant types showed major increases in 2017 to 2019 (Table 3). Although the number of villages producing traditional plant-type OPVs decreased over time, seed production of traditional plant-type hybrids increased dramatically (Table 3), with the hybrid 'Pablo', just registered in 2012, becoming the most frequently produced 
Table 5 Responsibilities assumed by different types of partners for activities conducted by the sorghum network in Mali (summarized from Weltzien et al. 2006; 2020)

\begin{tabular}{|c|c|c|c|}
\hline \multirow[t]{2}{*}{ Type of activity } & \multicolumn{3}{|l|}{ Responsibilities } \\
\hline & $\begin{array}{l}\text { Farmers, Farmer Cooperatives and } \\
\text { Unions }\end{array}$ & $\begin{array}{l}\text { NGO/Extension Development } \\
\text { Organizations }\end{array}$ & $\begin{array}{l}\text { Public Breeding and Seed Pro- } \\
\text { grams }\end{array}$ \\
\hline Variety creation and evaluation & $\begin{array}{l}\text { Set priorities } \\
\text { Progeny selection } \\
\text { Variety evaluation at fieldand post- } \\
\text { harvest events } \\
\text { Implement Variety Adaptation } \\
\text { Trials } \\
\text { Collect farmer feedback in villages }\end{array}$ & $\begin{array}{l}\text { Village facilitators training for } \\
\text { trial establishment } \\
\text { Prepare protocols/ templates for } \\
\text { documenting farmers' observa- } \\
\text { tions and assessments }\end{array}$ & $\begin{array}{l}\text { Create breeding populations } \\
\text { Multiply selected lines } \\
\text { Organize trials } \\
\text { Analyze results } \\
\text { Conduct feedback meetings } \\
\text { Variety registration }\end{array}$ \\
\hline Seed production & $\begin{array}{l}\text { Chose varieties for seed produc- } \\
\text { tion and order/distribute founda- } \\
\text { tion seed } \\
\text { Produce, store, clean and package } \\
\text { certified seed of OPV's, hybrids } \\
\text { and in some cases hybrid parents }\end{array}$ & $\begin{array}{l}\text { Train facilitators to monitor seed } \\
\text { production, processing and } \\
\text { storage } \\
\text { Train cooperatives for manage- } \\
\text { ment, accounting and marketing } \\
\text { skills }\end{array}$ & $\begin{array}{l}\text { Produce early-generation seed } \\
\text { Produce training materials } \\
\text { Conduct training on seed produc- } \\
\text { tion and seed certification } \\
\text { Organize exchange visits between } \\
\text { seed-cooperatives }\end{array}$ \\
\hline Seed marketing and dissemination & $\begin{array}{l}\text { Collect and record testimonies } \\
\text { from farmers for radio messag- } \\
\text { ing } \\
\text { Set and implement seed marketing } \\
\text { Implement direct seed sales to } \\
\text { farmers } \\
\text { Identify buyers for bulk sales of } \\
\text { seed } \\
\text { Identify (new) buyers of grain, e.g. } \\
\text { for new varieties with specific } \\
\text { traits }\end{array}$ & $\begin{array}{l}\text { Facilitate radio transmission of } \\
\text { information regarding varieties } \\
\text { and sale of seed }\end{array}$ & $\begin{array}{l}\text { Prepare and facilitate communica- } \\
\text { tion of varietal information (e.g. } \\
\text { fliers, seed packet labels etc.) } \\
\text { Facilitate organizational change } \\
\text { Facilitate linkages of Seed Coop- } \\
\text { eratives with other actors } \\
\text { Organize tools and procedures for } \\
\text { monitoring and data collection }\end{array}$ \\
\hline
\end{tabular}

variety in all zones. The second most frequently produced variety, 'Soubatimi', is a novel sweet-stem multi-purpose type that was just registered in 2015 .

\section{Organizational models and structures}

A major outcome of collaborative networks are organizational models that create collaborative advantages deriving from the different, complementary knowledge, experience and skills of organizations involved (Christinck et al. 2020). The farmer organizations, public breeding programs and development organization engaged in the sorghum network share common objectives of contributing to food and nutrition security, income generation and empowerment of farmers while having very different knowledge, experiences and skills (Christinck et al. 2020). The partners, over a decade or more of collaboration, arrived at detailed division of responsibilities (Table 5). The partners also developed complementary means of mobilizing access and use of resources such as land, germplasm, databases and analytical capacity.

Annual feedback and planning meetings have become a major forum for facilitating interactions among the network partners (Weltzien et al. 2008; 2020). These meetings have evolved to include three types of feedback: (1) breeders' summary presentations of the Stage- 1 multi-location variety trials; (2) farmer groups reporting Stage-2 'Adaptation Trial' observations and experiences; and (3) seed producers sharing experiences with specific OPV and hybrids varieties, seed certification and seed sales (Weltzien et al. 2008; 2019). Subsequently, topics for planning the upcoming seasons' activities are identified for small group discussions by different subgroups of farmers and local development partners. Each small group presents their discussion outcomes to the plenary by reporting, for example, objectives for adaptation trials, training requirements, or procedures for planning seed production (Weltzien et al. 2008). The plans and timelines for the upcoming seasons' activities are then finalized in plenary. These meetings thus enable joint assessment of achievements, bottlenecks and options for progress and the prioritization of objectives and activities in the context of each farmer organization and the practical experiences of its members.

Annual culinary testing activities enabled women's expertise in grain processing and use to be systematically integrated into the network, contributing to identifying varieties for advancement and seed production (Isaacs et al. 2018). Also, by requiring that women conduct their own Stage-2 Adaptation Trials for a village to participate, women and their groups gained direct involvement in activities as well as a voice in network decision making (Rattunde et al. 2018). 
Specific women's trials furthermore triggered changes in selection strategy to explicitly focus on adaptation to low soil-phosphorus, a problem that is most acute for women farmers (Leiser et al. 2012; 2018). In addition, nutrition research and varietal-monitoring for nutritional value was integrated into the collaborative breeding work as a result of women's involvement and focus on both grain quality as well as yield (Isaacs et al. 2018; Rattunde et al. 2018; Bauchspies et al. 2017). Thus, several organizational structures have enabled women's roles and agency in the network to grow and make critical contributions to its functioning.

The diverse and growing scale of network activities by numerous cooperatives proved to be challenging for the union of farmer cooperatives, ULPC, as it struggled to both coordinate and maintain transparency for its member cooperatives (Sidibé 2018, unpublished work). ULPC members and management thus engaged in a series of detailed discussions and negotiations that was monitored by a researcher from the network. A major outcome was the creation of local 'seed management committees' responsible for coordinating the various cooperatives in their commune (lowest administrative unit in Mali) (Sidibé 2018, unpublished work). These decentralized seed committees now plan all the seed-related activities, including production, storage, conditioning and sale, with the various cooperatives in their area (Y. Touré, personal communication 30 October 2019). Each local seed committee is represented in a newly created seed coordination committee at the union headquarters. This multilayered management structure is a novel development that is highly appreciated and has inspired ULPC to create additional committee systems for the environment, member services and gender (Y. Traoré, personal communication 30 October 2019).

\section{Elements of the traditional sorghum seed system maintained or transformed}

Nine elements of the traditional sorghum seed system were identified that were either maintained or transformed as the sorghum network's activities evolved.

\section{Collective 'ownership' of varieties}

In the traditional farmer-managed seed system, the concept of private ownership of sorghum varieties seems unknown; rather, varieties tend to be 'owned ' collectively by those who use them. The new varieties created by the network are also maintained as public goods with no intellectual property protection or exclusive licensing for seed production or dissemination. Breeders' seed of these varieties is maintained by the public breeding programs. Any farmer cooperative interested in multiplying and selling seed of a specific variety can request foundation seed from the breeding programs.
To comply with the requirements for seed certification, varieties developed by the network are registered in the national seed catalogue under the names of participating breeders and the farmer organizations, or individual farmers, if specific contributions for the selection, and identification of the varieties can be traced. In addition, certain farmers kept and disseminated seed of selected varieties from the participatory trials.

\section{Maintaining and using a range of different varieties}

Malian farmers cultivate a diverse range of sorghum varieties for different conditions and purposes (Bazile and Soumare 2004; Lacy et al. 2006; Siart 2008). The new varieties that were co-developed by the network strengthen this approach by offering novel plant types and new trait combinations, as described above. In the Malian traditional seed system, varieties may occasionally travel far, but this is limited to ad hoc initiatives of individual travelers or traders (Siart 2008). Through the growing number of collaborating farmer seedcooperatives, seed of new varieties is now available across larger geographic areas and reach a significant number of farm households in Mali and neighboring countries (Smale et al. 2018; Sissoko et al. 2019; vom Brocke et al. 2020).

\section{Creating new varieties}

The creation of new varieties in the traditional system is the outcome of individual farmers making single-plant selections in their own field, with the genetic diversity limited to the intra-varietal diversity present. The sorghum network builds on the individual farmers' skills in observation and selection, as well as their curiosity for testing new varieties (Lacy et al. 2006), while transforming it in multiple ways. For example, experimental designs and protocols for evaluating the same materials over multiple locations were co-created and introduced at many locations (Weltzien et al. 2020), allowing the integration of many individual farmers' observations, and facilitating their use by breeders and farmer seed-cooperatives. Furthermore, the entire approach builds systematically on making use of farmers' and breeders' complementary knowledge and access to resources (including diverse sources of germplasm) (Christinck et al. 2020). These transformations were critical for achieving progress in breeding for complex traits like yield, or the development of novel plant types with new trait combinations.

\section{Sharing information on varieties}

The sharing of information about new sorghum varieties in the traditional system depends on close social relationships and is, therefore, most often limited to local scale. Additionally, the cultural expectation that seed be given to 
someone in need, creates a disincentive for 'advertising' the advantages of new varieties. The communication of varietal information by farmer seed-cooperatives and their use of diverse, inclusive and novel communication strategies represent major transformations that facilitate large-scale and rapid spread of varietal information (Jones 2017). Knowledge sharing was also actively facilitated by, for example, forming groups of farmers within a village to conduct each type of trial and organizing exchange visits among cooperatives (Christinck et al. 2014). Village-level field days ("visites inter-paysans"), visits of researchers and technical staff to on-farm trials, new forms of documenting and sharing knowledge in written form (Weltzien et al. 2020) and at annual meetings expanded the pathways for knowledge sharing beyond what was previously practiced.

\section{Combining food and seed production}

Traditionally, sorghum farmers never sow entire fields for seed production but rather select desirable plants for seed prior to harvesting a field. Farmers who now produce seed for the network often deliver only a portion of their OPV seed-production plot harvest to sell as seed, keeping the rest as food grain. This practice is also intrinsic in hybrid seed production, with farmers selling the hybrid seed harvested from the female parent and using the grain harvested from the male parent for home consumption. Farmer's enthusiasm to produce hybrid seed appears to be due to the ability it offers to combine a 'cash crop' (hybrid seed from the female parent) with a food crop (grain from the male parent) in the same field (Weltzien et al., 2020).

\section{Saving seed from one's own harvest}

Farmer's ability and skills to select and save seed is a key aspect of the traditional sorghum seed system. Therefore, OPVs were the sole focus of network activities initially, and remains a major undertaking in terms of numbers of varieties created and disseminated (Table 3 ). When activities for developing hybrid varieties were first discussed, farmers indicated concerns about their ability to save and resow seed and whether seed of preferred hybrids would be available in subsequent years. However, over time these concerns decreased as farmers observed that some hybrids can be re-sown once or even several times and still show yield advantages (see above), and the farmer seed-cooperatives' enthusiasm and success at producing seed of the preferred hybrids and of their parents.

\section{Ensuring everyone's access to seed}

The sharing of seed with anyone who asks is fundamental in the traditional sorghum seed system. The seed cooperatives share or sell seed according to their own strategies, including providing seed on credit with repayment in kind as per traditional practices. Although the sale of seed by individuals is not traditionally acceptable, it is acceptable for cooperatives, through which benefits accrue to the group (Jones 2017; Sidibé 2018, unpublished work).

\section{Ensuring seed quality based on trusted relationships}

Trust, personal relationships and proximity underlie exchange and dissemination of sorghum seed in both the farmers' traditional system and within the network. Seed production by local cooperatives enabled farmers to visit seed production fields and meet or know the seed producers. The seed cooperatives realized the importance of social trust for successful seed sales and used these local strengths by, for example, ensuring that seed sellers had first-hand experiences with the varieties they sell, transmitting radio messages with the experiences of locally well-respected farmers, and including the names of the cooperative and seed producer on seed packets. Packaging seed in clear bags and labelling it with descriptions in local language also contributed to building trust (Jones 2017; Sidibé 2018, unpublished work).

\section{Acknowledging individual skills and expertise that contribute to the common good}

Village seed- or variety-specialists who invest special efforts in seed selection andproduction are important actors in the traditional system for sorghum in Mali and enjoy high recognition and esteem (Siart 2008; Lacy et al. 2006). The seedcooperative's reliance on farmers who are recognized as seed experts and who volunteer based on their strong interest in seed, builds on this tradition. The conduct of variety trials and seed production by such local seed experts is expected to increase the credibility of these activities, facilitating acceptance and sharing of seed of these new varieties by farmers who did not participate directly in the variety evaluations (Lacy et al. 2006; Jones 2017). The interaction among specialists from different villages and regions was new and powerful for joint learning.

\section{Discussion}

\section{'Developing' the seed system-but where to?}

'Seed sector development' has been identified as a key driver for fostering agricultural productivity, resilience, nutrition and economic growth in developing countries (e.g. Coomes et al. 2015; McGuire and Sperling 2016). However, most seed used in these countries ( $80-90 \%$ or more) stems from 
traditional farmer-managed systems (McGuire and Sperling 2016; Access to Seeds Foundation 2018). The limited success of interventions to 'modernize' the seed sector to better serve smallholder farmers is widely noted (e.g. Djamen 2016; McGuire and Sperling 2016).

Several factors have been cited as obstacles. High initial investments, along with fragmentation of supply and demand, present a challenging context, especially for private investors (Sagnard et al. 2008; Djamen 2016). Subsidized seed distribution programs, intended to facilitate smallholder farmers' access to certified seed, hinder the success of more market-based approaches and tend to benefit 'opportunistic' suppliers that, lacking rigor in provision of quality seed, can undermine trust (Djamen 2016; Christinck et al. 2018). Furthermore, interventions are sometimes planned based on vague needs analyses; for example, assessments of what is 'economic' for farmers may be too simplistic (e.g. Vitale 2018) not considering the crop's full internal use value or that only a portion of the harvest may be sold.

A general tension stems from diverse actors, including public, private and civil society, following competing narratives of how to best build innovative and sustainable seed systems, with divergent goals, underlying values, and levels of influence on policy formulation (Spielman and Kennedy 2016; McGuire and Sperling 2016) or under implicit assumptions of what a 'developed' or 'mature' seed sector entails (McGuire and Sperling 2016). Coomes et al. (2015) disprove several common misconceptions concerning farmers' seed systems, including that the latter are destined to weaken and disappear once commercial seed systems and related regulation are in place.

Tripp and Rohrbach (2001) identify a dividing line between (1) approaches for strengthening farmers' own seed production; or (2) their capacities as effective 'consumers' of commercial inputs. More recently, Integrated Seed Sector Development (ISSD) has been proposed as a 'twin track approach', where both the farmer-managed and the formal seed system are enhanced and their integration is promoted for various seed system activities, including genetic resources conservation, breeding, seed production and distribution (Louwaars and De Boef 2012).

How farmers themselves would develop seed systems seems to be little studied. The case documented here does represent an example where farmers had leading roles in the transformation of the seed system for one of their most important food crops.

The approach taken by the sorghum network in Mali was found to:

- affirm cultural values relating to seed, rather than considering them as a hindrance.

- add options to, rather than compete with, the traditional farmer-managed system.
- strengthen farmers' role as key actors in sorghum seed systems in general, rather than limiting it to specific subsections.

- integrate variety creation, seed production and dissemination, rather than focusing on a single seed system function or 'bottleneck'.

- allow farmers to actively contribute their knowledge and context-specific experience to all activities of the network, from priority setting to developing varieties to producing and distributing seed, rather than being dependent on information provided by others.

- allow local groups of farmers to produce and distribute seed of varieties co-developed by the network in response to their members' and customers' demand, rather than based on assessments made by 'outsiders' with economic self-interest.

\section{Commoning and features of a Seed Commons in the sorghum network}

Commoning as a social practice is argued to be based on "voluntary and inclusively self-organized activities and mediation of peers who aim at satisfying needs" (Euler 2018). Participation in the activities of the sorghum network is purely voluntary; they offer at lot of room for discussion at 'official' meetings as well as many other occasions (Weltzien et al. 2020). For example, almost all activities at local level are carried out in small groups of farmers, requiring joint reflection of observations, progress etc. Efforts have constantly been made to make group deliberations as inclusive and consent-oriented as possible, e.g. by involving facilitators and jointly establishing protocols for agreed-upon procedures (Weltzien et al. 2020).

The decentralized design of the network is a key feature that ensures a clear orientation towards local needs, along with possibilities to respond flexibly to changing conditions. However, the cooperatives are more than just an 'instrument' for distributing seed. They also promote social cohesion and political representation, e.g. via membership in larger umbrella organizations. This confirms experiences made elsewhere that community-based enterprises can be successful in that they are able to address broad sets of goals and create social values, meaning and identity, besides securing better access to the resources or goods in question (Berkes and Davidson-Hunt 2009).

The network's overall design and principles of organization can be related to the core features of Seed Commons identified by Sievers-Glotzbach et al. (2020).

Collective responsibility underlies the entire approach. Responsibilities of farmers and public institutions, such as national and international breeding programs were previously fragmented by their focus on different environments and varieties (Lacy et al. 2006) and relying on different 
actors, knowledge, processes and rules. Whereas the traditional seed system emphasized collective responsibility to ensure seed security, the public research organizations focused on creating new varieties. By undertaking joint activities, the responsibilities of actors and institutions participating in the sorghum network were expanded and redefined to serve shared goals (Table 5) integrating variety creation and seed-production and dissemination.

Knowledge sharing is fundamental to the network activities and takes place at multiple levels: within and among the groups of collaborating farmers, among farmers and researchers, among researchers from national and international breeding programs (Christinck et al. 2020), and across levels of operation. The presented case however not only engages in sharing knowledge but also on actively connecting the knowledge held by various actors, taking advantage of its complementarity (Christinck et al. 2020) and embodying it into new practices (e.g. new trial designs, and farming practices) and products (e.g. novel variety types) (Weltzien et al. 2020).

The co-creation of new varieties in Mali, for example, involved jointly applying the knowledge of farmers (e.g. traits required for adaptation and quality, observation skills) and breeders (e.g. statistical and quantitative-genetic support, awareness of new traits for quality, adaptation or resistance).

Most of the Sorghum Network's practical activities and related organizational structures can be summarized under polycentric management. While fundamental decisions on the orientation of the breeding program are made jointly, the main activities, such as variety testing, choice of varieties for seed production or modes of marketing, are organized in a decentralized manner, with farmer cooperatives or local groups of members deciding independently on key operational issues.

The annual meetings play an important role for facilitating joint reflection on experiences and results, shared planning and problem solving as well as prevention and resolution of conflicts. Seed committees coordinate activities across levels and facilitate communication among members of a union of farmer cooperatives. The general assemblies of individual cooperatives likewise represent organizational structures for ensuring collective management at the local level.

Following the model of the traditional farmer-managed system, protection from private enclosure is primarily understood as an obligation (or willingness) to share. Individual farmers continue to share seed, following traditional practices. Variety protection is not sought by the sorghum network and there is no exclusive licensing for seed production. Any farmer cooperative can register as a seed producer organization and submit their orders for foundation seed to the national breeding program. Access to foundation seed is essential for the functioning of the decentralized model of seed production and distribution, allowing individual cooperatives to respond to variety and seed demand of their respective user communities. Varieties co-developed by ICRISAT are also shared with users globally via the Multilateral System (MLS) of the ITPGRFA, thus establishing linkages between local and global Seed Commons.

Considerations concerning defensive protection to prevent appropriation by others (López Noriega 2016) are not very advanced within the sorghum network; the focus has been on facilitating use of the co-developed varieties, rather than restricting it in any way. However, varieties have been registered in the National Variety Catalogue, with the necessary documentation of varietal traits and performance. This provides some level of protection, although strategies could still be improved (López Noriega 2016). However, as the network's diverse actors increase their joint engagementand stake in variety creation, seed availability and access, dialogue on seed legislation and regulations from a commons perspective will likely grow.

\section{Contributions towards global development goals}

The sorghum network was initiated to better fulfil the mandate of the participating organizations. While the mandate of farmer organizations is defined by their members, those of national and international public breeding organizations are mostly derived from international and national policy agendas. For ICRISAT, for example, the Research Program for Grain Legumes and Dryland Cereals (Sharma 2020) contributes to three CGIAR system level outcomes: reducing poverty, improving food and nutrition security, and improving natural resources and ecosystem services. Intermediate development outcomes expected to contribute to these system-level outcomes include increased productivity and food security, and increased resilience and incomes for the rural poor.

Contributions to these strategic goals are thus considered by the participating breeding programs as primary measures of success. The substantial yield-superiorities of the collaboratively-developed varieties over local varieties (Smale et al. 2018; Weltzien et al. 2018) under both poor as well as favorable conditions (Weltzien et al. 2008; 2018; Rattunde et al. 2013; Kante et al. 2017,) suggest that the sorghum network is contributing to the food security of smallholder farmers. An impact study found that farmers cultivating these new varieties, particularly the hybrids, reduced the share of sorghum grain they had to purchase for home consumption (Smale et al. 2018). Furthermore, these farmers widened the range of food items they consumed, suggesting that nutritional improvement through dietary diversification is possible (Smale et al. 2018). 
Contributions to agrobiodiversity and resilience can also be expected from various outcomes of the sorghum network. The large and changing portfolio of varieties co-created and in seed production by the sorghum network (Table 3) provides a direct indicator. The network's emphasis on local (Guinea-race) germplasm for breeding new varieties (Weltzien et al. 2006; Diallo et al. 2019), rather than the earlier focus on exotic germplasm (Yapi et al. 2000), is expected to favor adaptation to widely prevalent threats such as grain mold (Weltzien et al. 2018), poor soil conditions (Leiser et al. 2012), and the complex of stresses associated with rainfall variability (Clerget et al. 2008).

Furthermore, the availability of varieties with novel traits opens new opportunities for smallholder farming system diversification and resilience. A major example is that of improved fodder-quality, which when combined with the good quality grain of the local Guinea-race sorghums, enables new and multiple uses of this traditional food crop that enhances overall farm-output and income stability. Furthermore, the improved availability of livestock feed, especially in the dry-season, can greatly facilitate crop-livestock integration and its multiple benefits, directly as well as indirectly, such as through enhanced availability of manure and compost for improving soil water-holding capacity and fertility.

\section{Replicability of the approach}

The sorghum network in Mali is not simply an 'outlier' that arose in a favorable context. A study conducted by Access to Seed Foundation (2018) found that farmer-managed seed cooperatives are active in at least in 17 countries of West and Central Africa, often cooperating with national breeding and research programs. Similar models were also documented in detail for sorghum in Burkina Faso (Christinck et al. 2014; vom Brocke et al. 2014; 2020) and pearl millet in Niger (Christinck et al. 2014). In Vietnam, 'Farmer Seed Clubs' engage in breeding, variety evaluation, large-scale seed production and marketing of rice seed in collaboration with the Mekong Delta Research and Development Institute and local government authorities (Tin et al. 2011; SEARICE 2007). What role commons features play in each of these networks would be a subject for future research.

\section{Conclusions and outlook}

This study of the sorghum network and its evolution shows how a process emphasizing collective responsibility and distributed decision-making has the potential to strengthen and further variety and seed governance of an indigenous staple cereal crop in Mali.
This transformation was enabled by creating an inclusive framework for collaboration involving farmer organizations, public breeding programs and various other partners (e.g. NGOs and extension agents). The way that relationships within the network were shaped and strengthened was a decisive factor for success; commoning as a social process was facilitated at multiple levels, with farmers contributing to priority setting at the network level while practicing locallevel decision-making.

By taking on collective responsibility for breeding and seed dissemination, the previously observed fragmentation of responsibilities and actors was overcome. The integration of breeding and seed activities creates dynamics that enable responsiveness to the diversity of evolving challenges and opportunities in a timelier manner. This represents an alternative model for organizing breeding programs that can respond with an appropriate diversity of varietal options at scale while the dissemination of seed of these varieties is accelerated.

The sorghum network, through reliance on and strengthening of core features of Seed Commons, proved capable of increasing agricultural productivity, food security and agrobiodiversity. Contributions to the transformation of farming and food systems towards sustainability and resilience can thus be made using this approach that emphasizes local aspirations and leadership in a wider collaborative network pursuing global development agendas.

Acknowledgements The authors appreciate the contributions of Willmar Leiser and Stephan von Borstel for preparing and editing the map of sorghum network partners and the IER and ICRISAT sorghum breeding programs for providing the coordinates. Helpful comments and suggestions made by Stefanie Sievers-Glotzbach and Julia Tschersich at Carl von Ossietzky Universität Oldenburg on earlier versions of this paper are gratefully acknowledged.

Open Access This article is licensed under a Creative Commons Attribution 4.0 International License, which permits use, sharing, adaptation, distribution and reproduction in any medium or format, as long as you give appropriate credit to the original author(s) and the source, provide a link to the Creative Commons licence, and indicate if changes were made. The images or other third party material in this article are included in the article's Creative Commons licence, unless indicated otherwise in a credit line to the material. If material is not included in the article's Creative Commons licence and your intended use is not permitted by statutory regulation or exceeds the permitted use, you will need to obtain permission directly from the copyright holder. To view a copy of this licence, visit http://creativecommons.org/licenses/by/4.0/.

\section{References}

Abdulai, Alhassan L., Mamoutou Kouressy, Michel Vaksmann, Folkhard Asch, Marcus Giese, and Holger Brueck. 2012. Latitude and Date of Sowing Influences Phenology of 
Photoperiod-Sensitive Sorghums. Journal of Agronomy and Crop Science 198: 340-348.

Access to Seeds Foundation. 2018. The Rise of the Seed-producing Cooperative in Western and Central Africa. Amsterdam: Access to Seeds Foundation. https://www.accesstoseeds.org/seed-produ cing-cooperatives-improve-access-to-quality-seeds-in-west-andcentral-africa/. Accessed 12 October 2019.

Bazile, Didier, and Mamy Soumare. 2004. Gestion spatiale de la diversité variétale en réponse à la diversité écosystémique: le cas du sorgho [Sorghum bicolor (L) Moench] au Mali. Cahiers d'Agriculture 13: 1-8.

Bauchspies, Wenda, Fatim Diarra, Fred Rattunde, and Eva Weltzien. 2017. "An Be Jigi": collective cooking, whole grains \& technology transfer in Mali. Facets. https://doi.org/10.1139/facet s-2017-0033.

Berkes, Fikret, and Iain J. Davidson-Hunt. 2009. Innovating through commons use: community-based enterprises. International Journal of the Commons 4 (1): 1-7.

Bollier, David. 2014. The commons as a template for transformation. Great Transformation Initiative. https://greattransition.org/publi cation/the-commons-as-a-template-for-transformation. Accessed 16 October 2019.

Christinck, Anja, Marthe Diarra, and Gottfried Horneber. 2014. Innovations in seed systems: Lessons from the CCRP-funded Project "Sustaining Farmer-Managed Seed Initiatives in Mali, Niger, and Burkina Faso”. Minneapolis: McKnight Foundation.

Christinck, Anja, Fred Rattunde, Alpha Kergna, Wellington Mulinge, and Eva Weltzien. 2018. Identifying Options for the Development of Sustainable Seed systems - Insights from Kenya and Mali. ZEF Working Paper No. 165. Bonn: Center for Development Research (ZEF).

Christinck, Anja, Fred Rattunde, and Eva Weltzien. 2020. Building collaborative advantages through long-term farmer-breeder collaboration: practical experiences from West Africa. 2019. In Farmers and plant breeding. Current approaches and perspectives, eds. Ola T. Westengen and Tone Winge, 178-195. Abingdon and New York: Routledge.

CILSS. 2016. Le Catalogue Régional CEDEAO-UEMOA-CILSS des Espèces et Variétés Végétales. Comité permanent Inter-Etats de Lutte contre la Sécheresse dans le Sahel (CILSS).https://insah .cilss.int/index.php/2017/12/07/catalogue_des_semences/. Accessed 18 November 2019.

Clerget, Benoit, Michael Dingkuhn, H. Eric Gozé, Frederick W. Rattunde, and Bertrand Ney. 2008. Variability of phyllochron, plastochron and rate of increase in height in photoperiod-sensitive Sorghum varieties. Annals of Botany 101 (4): 579-594.

Coomes, Oliver T., Shawn J. McGuire, Eric Garine, Sophie Caillon, Doyle McKey, Elise Demeulenaare, Devra Jarvis, Guntra Aistara, Adeline Barnaud, Pascal Clouvel, Laure Emperaire, Sélim Louafi, Martin Pierre, François Massolo, Marco Pautasso, Chloé Violon, and Jean Wencélius. 2015. Farmer seed networks make a limited contribution to agriculture? Four common misconceptions. Food Policy 56: 41-50.

Coulibaly, Harouna, Bazile Didier, Amadou Sidibé, and Géraldine Abrami. 2008. Les systèmes d'approvisionnement en semences de mils et sorghos au Mali : production, diffusion et conservation des variétés en milieu paysan. Cahiers Agricultures 17: 199-209.

Coulibaly, Harouna, Didier Bazile, and Amadou Sidibé. 2014. Modelling seed system networks in Mali to improve farmers' seed supply. Sustainable Agriculture Research 3 (4): 18-32.

Coulibaly, Jeanne Y., John H. Sanders, Paul V. Preckel, and Timothy G. Baker. 2015. Will cotton make a comeback in Mali? Agricultural Economics 46 (1): 53-67. https://doi.org/10.1111/agec.12140.

Dalohoun, Daniel, Paul Van Mele, Eva Weltzien, Dioukamady Diallo, Hamidou Guindo, and Kirsten vom Brocke. 2011. Mali: When government gives entrepreneurs room to grow. In African Seed
Enterprises: Sowing the Seeds of Food Security, eds. Paul Van Mele, Jeffery W. Bentley, and Robert G. Guéi, 65-88. Rome: Food and Agriculture Organization of the United Nations (FAO) and Cotonou: AfricaRice.

De Jonge, Bram, Gigi Manicad, Andrew Mushita, Normita G. Ignacio, Alejandro Argumedo, and Bert Visser. 2019. Seed laws. Bottlenecks and opportunities in participatory plant breeding. In Farmers and plant breeding. Current approaches and perspectives, eds. Ola T. Westengen and Tone Winge, 277-293. Abingdon and New York: Routledge.

Deu, Monique, Eva Weltzien, Caroline Calatayud, Yalaly Traoré, Didier Bazile, Eric Gozé, Gilles Trouche, and Kirsten vom Brocke. 2014. How an improved sorghum variety evolves in a traditional seed system in Mali: Effects of farmers' practices on the maintenance of phenotype and genetic composition. Field Crops Research 167: 131-142.

Diakité, Soriba. 2003. Le système semencier local : Description, évaluation et valorisation (Cas du sorgho dans sept villages au Mali). Working Papers on Local Knowledge No. 2. Point Sud: Bamako.

Diallo, Chiaka, Krista Isaacs, Vernon Gracen, Aboubacar Touré, Eva Weltzien Rattunde, Eric Y. Danquah, Mamourou Sidibé, Daniel K. Dzidzienyo, Fred Rattunde, and Baloua Nébié. 2018. Learning from farmers to improve Sorghum breeding objectives and adoption in Mali. Journal of Crop Improvement 32 (6): 829-846.

Diallo, Chiaka, H. Frederick, W. Rattunde, Vernon Gracen, Aboubacar Touré, Baloua Nebié, Willmar Leiser, Daniel K. Dzidzienyo, Ibrahima Sissoko, Eric Y. Danquah, Abdulaye G. Diallo, Bakaro Sidibé, Mamourou Sidibé, and Eva Weltzien. 2019. Genetic diversification and selection strategies for improving Sorghum grain yield under phosphorous-deficient conditions in West Africa. Agronomy 9 (11): 742.

Djamen, Patrice. 2016. Developing the seed sector to increase agricultural productivity in West and Central Africa. Key interventions areas and guiding principles. Policy Brief. Conseil Ouest et Centre Africain pour la Recherche et le Développement Agricoles (CORAF)/West and Central African Council for Agricultural Research and Development (WECARD): Dakar. https ://www.coraf.org/wasp2016/wp-content/uploads/2016/11/VR_-Report-3bis-_-Eng-_-Key-Interventions-areas-and-guidingprinciples-for-the-dvpt-of-seed-sector-in-WCA.pdf. Accessed 15 December 2019.

Eisenhardt, Kathleen M., and Melissa E. Graebner. 2007. Theory building from cases: challenges and opportunities. Academy of Management Journal 50 (1): 25-32.

Euler, Johannes. 2018. Conceptualizing the commons: Moving beyond the goods-based definition by introducing the social practices of commoning as vital determinant. Ecological Economics 143: 10-16.

Fick, Stephen E., and Robert J. Hijmans. 2017. WorldClim 2: new $1-\mathrm{km}$ spatial resolution climate surfaces for global land areas. International Journal of Climatology 37 (12): 4302-4315.

Frischmann, Brett M., Michael J. Madison, and Katherine Jo Strandburg (eds.). 2014. Governing Knowledge Commons. Oxford and New York: Oxford University Press.

Halewood, Michael D. 2013. What kind of goods are plant genetic resources for food and agriculture? Towards the identification and development of a new global commons. International Journal of the Commons 7 (2): 278-312.

Harlan, Jack R., and Jan M.J. de Wet. 1972. A Simplified classification of cultivated Sorghum. Crop Science 12: 172-176.

Haussmann, Bettina I.G., Fred Rattunde, Eva Weltzien-Rattunde, Pierre S.C. Traoré, Kirsten vom Brocke, and Heiko K. Parzies. 2012. Breeding strategies for adaptation of Pearl Millet and Sorghum to climate variability and change in West Africa. Journal of Agronomy and Crop Science 198: 327-339. 
Helfrich, Silke, and David Bollier. 2019. Frei, fair und lebendig: Die Macht der Commons. Transcript: Bielefeld.

Herrmann, Ludger, Bettina I.G. Haussmann, Tom van Mourik, Pierre S. Traoré, Hannatou M. Oumarou, Kalifa Traoré, Mahama Ouedraogo, and Jesse Naab. 2013. Coping with climate variability and change in research for development targeting West Africa: need for paradigm changes. Sécheresse 24: 294-303.

Isaacs, Krista, Eva Weltzien, Chiaka Diallo, Mamourou Sidibé, Bocar Diallo, and Fred Rattunde. 2018. Farmer Engagement in Culinary Testing and Grain-Quality Evaluations Provides Crucial Information for Sorghum Breeding Strategies in Mali. In State of the Knowledge for Gender in Breeding: Case Studies for Practitioners, eds. Hale Ann Tufan, Stefania Grando, and Catherine Meola, 74-85. Lima: CGIAR Gender and Breeding Initiative.

Jarvis, Andy, Hari D. Upadhyaya, C.L.L. Gowda, Pramod K. Aggarwal, Sam Fujisaka, and Ben Anderson. 2010. Climate Change and its Effect on Conservation and Use of Plant Genetic Resources for Food and Agriculture and Associated Biodiversity for Food Security. Thematic Background Study. Rome: Food and Agriculture Organization of the United Nations (FAO).

Joyner, Christopher C. 2001. Global Commons: The Oceans, Antarctica, the Atmosphere, and Outer Space. In Managing Global Issues: Lessons Learned, ed. Peter J. Simmonds, and Chantal de Jonge Oudraat, 354-391. Washington D.C.: Carnegie Endowment for International Peace.

Jones, Kristal. 2017. Social institutions mediating seed access in West African seed systems. Facets. https://doi.org/10.1139/facet s-2017-0019.

Kante, Moctar, H. Fred, W. Rattunde, Willmar L. Leiser, Baloua Nebié, Bocar Diallo, Abdulaye Diallo, Abocar O. Touré, Eva Weltzien, and Bettina I.G. Haussmann. 2017. Can tall Guinea-Race Sorghum hybrids deliver yield advantage to smallholder farmers in West and Central Africa? Crop Science 57: 1-10.

Lacy, Scott M., David A. Cleveland, and Daniela Soleri. 2006. Farmer choice of Sorghum varieties in Southern Mali. Human Ecology 34 (3): 331-353.

Leiser, Willmar L., H. Frederick, W. Rattunde, Hans-Peter Piepho, Eva Weltzien, Abdoulaye Diallo, Albrecht E. Melchinger, Heiko K. Parzies, and Bettina I.G. Haussmann. 2012. Selection strategy for Sorghum targeting phosphorus-limited environments in West Africa: analysis of multi-environment experiments. Crop Science 52: 2517-2527.

Leiser, Willmar L., H. Frederick, W. Rattunde, Eva Weltzien, and Bettina I.G. Haussmann. 2014. Phosphorus uptake and use efficiency of diverse West and Central African Sorghum genotypes under field conditions in Mali. Plant and Soil 377: 383-394.

Leiser, Willmar L., H. Frederick Weltzien-Rattunde, Eva WeltzienRattunde, and Bettina I.G. Haussmann. 2018. Sorghum Tolerance to Low-Phosphorus Soil Conditions. In Achieving Sustainable Cultivation of Sorghum: Genetics, Breeding and Production Techniques (Volume 1), ed. William Rooney, 247-272. Cambridge: Burleigh Dodds Science Publishing.

López Noriega, Isabel. 2016. Defensive protection of farmers' varieties. In Farmers' Crop Varieties and Farmers' Rights. Challenges in Taxonomy and Law, ed. Michael Halewood, 212-248. Abingdon/ New York: Routledge.

Louwaars, Niels P., and Walter S. de Boef. 2012. Integrated seed sector development in Africa: A conceptual framework for creating coherence between practices, programs, and policies. Journal of Crop Improvement 26 (1): 39-59.

McGuire, Shawn, and Louise Sperling. 2016. Seed systems smallholder farmers use. Food Security 8 (1): 179-195.

Mudiwa, Morris. 2002. Global Commons: The Case of Indigenous Knowledge, Intellectual Property Rights and Biodiversity. The Commons in an Age of Globalisation. The Ninth Biennial
Conference of the International Association for the Study of Common Property. June 17-21, Victoria Falls, Zimbabwe.https://hdl. handle.net/10535/428. Accessed 27 July 2020.

Ollenburger, Mary H., Katrien Descheemaeker, Todd A. Crane, Ousmane M. Sanogo, and Ken E. Giller. 2016. Waking the sleeping giant: agricultural intensification, extensification or stagnation in Mali’s Guinea Savannah. Agricultural Systems 148: 58-70.

Ostrom, E. 1990. Governing the Commons. The evolution of institutions for collective action. Cambridge: Cambridge University Press.

Ostrom, Elinor (ed.). 2005. Understanding Institutional Diversity. Princeton: Princeton University Press.

Rattunde, H. Fred W., Eva Weltzien, Bocar Diallo, Abdoulaye G. Diallo, Mamourou Sidibe, Abocar O. Touré, Abishek Rathore, Roma R. Das, Willmar L. Leiser, and Aboubacar Touré. 2013. Yield of photoperiod-sensitive sorghum hybrids based on guinearace germplasm under farmers' field conditions in Mali. Crop Science 53 (6): 2454-2456.

Rattunde, H. Fred W., Sebastian Michel, Willmar L. Leiser, HansPeter Piepho, Chiaka Diallo, Kirsten vom Brocke, Bettina I.G. Haussmann, and Eva Weltzien. 2016. Farmer Participatory EarlyGeneration Yield Testing of Sorghum in West Africa: Possibilities to Optimize Genetic Gains for Yield in Farmers' Fields. Crop Science 56 (5): 2493-2505.

Rattunde, Fred, Mamourou Sidibé, Bocar Diallo, Eva van den Broek, Hermann Somé, Kirsten vom Brocke, Aboudalye Diallo, Baloua Nebie, Aboubacar Touré, Krista Isaacs, and Eva Weltzien. 2018. Involving women farmers in variety evaluations of a "men's crop": Consequences for the sorghum breeding strategy and farmer empowerment in Mali. In State of the Knowledge for Gender in Breeding: Case Studies for Practitioners, eds. Tufan, Hale Ann, Stefania Grando and Catherine Meola, 95-107. Lima: CGIAR Gender and Breeding Initiative.

Ridder, Hans-Gerd. 2017. The theory contribution of case study research designs. Business Research 10 (2): 281-305.

Ridder, De, Henk Breman Nico, Herman van Keulen, and Tjeerd Jan Stomph. 2004. Revisiting a 'Cure against Land Hunger': soil fertility management and farming systems dynamics in the West African Sahel. Agricultural Systems 80: 109-131.

Sagnard, Fabrice, Adeline Barnaud, Monique Deu, Clarisse Barro, Claude Luce, Claire Billot, Jean-François Rami, Sophie Bouchet, Dékoro Dembélé, Virginie Pomiès, Caroline Calatayud, Ronan Rivallan, Hélène Joly, Kirsten Vom Brocke, Aboubacar Touré, Jacques Chantereau, Gilles Bezançon, and Michel Vaksmann. 2008. Analyse multiéchelle de la diversité génétique des sorghos : compréhension des processus évolutifs pour la conservation in situ. Cahiers d'Agriculture 17: 114-121.

SEARICE. 2007. Good quality seeds from farmers' seed clubs. LEISA Magazine 23 (2): 24-26.

Sharma, Kiran K. 2020. CGIAR Research Program on Grain Legumes and Dryland Cereals (CRP-GLDC). Annual Report 2019. Montpellier: Consultative Group on International Agricultural Research (CGIAR) and partners.

Siart, Sonja. 2008. Strengthening local seed systems: Options for enhancing diffusion of varietal diversity of sorghum in Southern Mali. Communication and Extension Series No. 85. Weikersheim: Margraf Publishers.

Sievers-Glotzbach, Stefanie, Julia Tschersich, Nina Gmeiner, Lea Kliem, and Anoush Ficiciyan. 2020. Diverse Seeds - Shared Practices: Conceptualizing Seed Commons. International Journal of the Commons. https://doi.org/10.5334/ijc.1043.

Sissoko, Mamadou, Melinda Smale, Annick Castiaux, and Veronique Thériault. 2019. Adoption of new sorghum varieties through a participatory approach. Sustainability 11 (17): 4780.

Smale, Melinda, Adama Assima, Alpha Kergna, Veronique Thériault, and Eva Weltzien. 2018. Farm family effects of adopting improved 
and hybrid sorghum seed in the Sudan Savanna of West Africa. Food Policy 74: 162-171.

Spielman, David J., and Adam Kennedy. 2016. Towards better metrics and policymaking for seed system development: Insights from Asia's seed industry. Agricultural Systems 147: 111-122.

Stake, Robert E. 2005. Qualitative case studies. In The SAGE handbook of qualitative research, 3rd ed, ed. Norman K. Denzin and Yvonna S. Lincoln, 443-466. London/Thousand Oaks: Sage Publications.

Tin, Huynh Quang, Nguyen Hong Cuc, Tran Tanh Be, Normita Ignacio, and Trygve Berg. 2011. Impacts of seed clubs in ensuring local seed systems in the Mekong Delta, Vietnam. Journal of Sustainable Agriculture 35 (8): 840-854.

Traore, Bouba, Marc Corbeels, Mark T. van Wijk, Mariana C. Rufino, and Ken E. Giller. 2013. Effects of climate variability and climate change on crop production in Southern Mali. European Journal of Agronomy 49: 115-125.

Tripp, Robert, and David Rohrbach. 2001. Policies for African seed enterprise development. Food Policy 26: 147-161.

Vitale, Jeffrey. 2018. Importance of sorghum in the Mali economy: the role of prices in economic growth, agricultural productivity and food security. Background paper to the UNCTAD-FAO Commodities and Development Report 2017. Rome: Food and Agriculture Organization of the United Nations (FAO).

Brocke, Vom, Gilles Trouche Kirsten, Eva Weltzien, Clarisse P. Kondombo-Barro, Adama Sidibé, Robert Zougmoré, and Eric Gozé. 2014. Helping farmers adapt to climate and cropping system change through increased access to sorghum genetic resources adapted to prevalent sorghum cropping systems in Burkina Faso. Experimental Agriculture 50: 284-305.

vom Brocke, Kirsten, Clarisse P. Kondombo, Marion Guillet, Roger Kaboré, Adama Sidibé, Ludovic Temple, and Gilles Trouche. 2020. Impact of Participatory Sorghum Breeding in Burkina Faso. Agricultural Systems 180: 102775.

Weltzien, Eva, and Anja Christinck. 2017. Participatory Plant Breeding: Developing Improved and Relevant Crop Varieties with Farmers. In Agricultural Systems: Agroecology and Rural Innovation for Development, ed. Sieglinde Snapp and Barry Pound, 259-301. Burlington/London: Academic Press.

Weltzien, Eva, Anja Christinck, Aboubacar Touré, Fred Rattunde, Mamoutou Diarra, Abdoullaye Sangaré, and Mamadou Coulibaly. 2006. Enhancing farmers' access to sorghum varieties through scaling-up participatory plant breeding in Mali, West Africa. In Bringing Farmers Back into Breeding. Experiences with Participatory Plant Breeding and Challenges for Institutionalisation, eds. Conny Almekinders and Jaap Hardon, 58-69. Wageningen: Agromisa Foundation.

Weltzien, Eva, Moussa Kanouté, Aboubacar Toure, Fred Rattunde, Bocar Diallo, Ibrahima Sissoko, Arouna Sangare, and Sonja Siart. 2008. Sélection participative des variétés de sorgho à l'aide d'essais multilocaux dans deux zones cibles. Cahiers Agricultures 17: 134-139.

Weltzien, Eva, H. Frederick, W. Rattunde, Tom A. van Mourik, and Hakeem A. Ajeigbe. 2018. Sorghum cultivation and improvement in West and Central Africa. In Achieving sustainable cultivation of sorghum: Sorghum utilization around the world, ed. William Rooney, 217-240. Cambridge: Burleigh Dodds Science Publishing.

Weltzien, Eva, Fred Rattunde, Mamourou Sidibé, Kirsten vom Brocke, Abdoulaye Diallo, Bettina Haussmann, Bocar Diallo, Baloua Nebie, Aboubacar Toure, and Anja Christinck. 2020. Long-term collaboration between farmers' organizations and plant breeding programmes: Sorghum and pearl millet in West Africa. In Farmers and plant breeding. Current approaches and perspectives, eds. Ola T. Westengen and Tone Winge, 29-48. Abingdon/New York: Routledge.
Yapi, Atse M., Alpha O. Kergna, Siegfried K. Debrah, Amadou S. Sidibé, and Ousman Sanogo. 2000. Analysis of the economic impact of sorghum and millet research in Mali. Patancheru: International Crops Research Institute for the Semi-arid Tropics (ICRISAT).

Publisher's Note Springer Nature remains neutral with regard to jurisdictional claims in published maps and institutional affiliations.

Fred Rattunde $(\mathrm{PhD})$ is a plant breeder engaged in farmer-participatory breeding and seed-system development. His long-term work with the International Crops Research Institute for the Semi-Arid Tropics (ICRISAT) focused on sorghum improvement and seed system development in collaboration with national breeding programs and farmer organizations in India and West Africa. Since 2016 he is a free-lance consultant and Honorary Associate at the University of Wisconsin-Madison.

Eva Weltzien (Dr. agr) is a conventionally trained plant breeder. Her research focused on the effective use of sorghum, pearl millet and barley genetic resources for variety development and seed systems that best meet women and men farmers' needs in dryland production areas, such as the Syrian Steppe, the Thar Desert of Rajasthan, India, and sub-Sahelian zones of West Africa. She has coordinated research on sorghum improvement in West-Africa for ICRISAT focusing on methodologies for participatory plant breeding to address farmers' production constraints and meet family needs for food and other products. Her research on enhancing local seed systems has resulted in an active network of farmer seed producer cooperatives in several West-African countries. In 2015 she was awarded the 'Justus von Liebig Prize for World Nutrition', jointly with her husband Fred Rattunde.

Mamourou Sidibé is an agronomist with a MS degree in rural development studies and specialized in participatory-research and networking. He works with many NGOs and farmer's organizations on participatory breeding and seed system development in West Africa as a Scientific Officer at the International Crops Research Institute for the Semi-Arid Tropics (ICRISAT). Prior to joining ICRISAT in 2000, he worked in a crop-physiology team at the Institut d'Economie Rurale (IER) at Sotuba, Mali.

Abdoulaye Diallo $(\mathrm{PhD})$ is the director of the Sorghum Improvement Program of the Institut d'Economie Rural (IER) since 2016 and heads the IER Sorghum-Breeding Program since 2007. His research contributed to development and diffusion of novel dual-purpose (grain and fodder) varieties of sorghum, the development of the first hybrid seed-parents based on Guinea-race germplasm, and the release of ten Guinea-race sorghum hybrids. He also contributed to training farmer seed-cooperatives in hybrid seed production techniques. He obtained his PhD in Plant Breeding from the University of Bamako in 2013.

Bocar Diallo is a plant breeder working with the Sorghum Breeding Program of the Institut d'Economie Rural (IER) in Mali since 2003. $\mathrm{He}$ is responsible for farmer-participatory and on-station activities of the IER Sorghum Breeding Program since 2006. His long-term engagement in farmer-participatory variety testing activities contributed to the continuity of IER's collaboration with numerous farmer organizations. He obtained his Master's degree at U.S.T.T.B. (University of Science, Technology and Technology of Bamako).

Kirsten vom Brocke (Dr. agr) is a scientist at the French Centre de Coopération Internationale en Recherche Agronomique pour le Développement (CIRAD) integrated in the Joint Research Unite "Genetic Improvement and Adaptation of Mediterranean and Tropical Plants (AGAP)". She has been involved in participatory sorghum breeding 
programs in collaboration with national breeding programs, NGOs and farmer organizations in Burkina Faso and Mali and is presently working on participatory upland rice improvement in Madagascar.

Baloua Nebié $(\mathrm{PhD})$ is a plant breeder who currently works as a Senior Scientist at the International Crops Research Institute for the Semi-Arid Tropics (ICRISAT), where he leads the Sorghum Breeding Program for West and Central Africa. His activities are focused on farmer-participatory breeding of hybrids and open-pollinated varieties and seed-system development through capacity building of local seed enterprises. $\mathrm{He}$ holds $\mathrm{PhD}$ and MSC degrees in Genetics and Plant Improvement.

Aboubacar Touré $(\mathrm{PhD})$ is an experienced sorghum breeder who established the sorghum breeding program of the Institut d'Economie Rurale in Mali. He maintained an active network of international, regional and national collaborators over many years. With these experiences he developed and implemented AGRA - Pass's (Alliance for a Green Revolution in Africa - Program for African Seed Systems) support program for National breeding programs in West Africa. Since 2016 he leads sorghum breeding efforts for West and Central Africa of the International Crops Research Institute for the Semi-Arid Tropics (ICRISAT).

Yalaly Traoré is a trained agronomist specializing in plant breeding and seed production. He works since 2009 as a technical advisor for the Local Union of Cereal Producers (ULPC) of Dioila-Mali. He is responsible for coordinating and monitoring ULPC's project implementation. His specific duties include supporting ULPC- farmers in their participatory varietal improvement and seed production activities, developing approaches to seed dissemination at the local level, and identifying capacity-building needs of ULPC members and seed committees.

Amadou Sidibé is a seed technologist who worked at the national agriculture research institution (Institut d'Economie Rurale, IER) in Mali since 1983. He is the Head of the Genetic Resource Unit of IER since 2001 . He worked for 12 years in seed certification prior to plant taking up responsibilities for genetic resources for IER following his graduate studies in the USA (1998). Through his work in partnership with Bioversity International, FAO, Global Crop Diversity Trust, local NGOs, and farmer organizations he contributed to developing participatory approaches (seed fairs, diversity field fora, community seed and gene banks) to promote seeds systems, plant genetic conservation and sustainable use.

Chiaka Diallo $(\mathrm{PhD})$ focuses his research primarily on participatoryand molecular plant-breeding. He is currently an Assistant Professor at l'Institut Polytechnique Rural de Formation et de Recherche Appliquée
(IPR/IFRA), Katibougou, Mali. He previously worked for eight years as a Research Assistant in the Sorghum Breeding Program of the national Institut d'Economie Rurale (IER) and collaborated closely with the International Crops Research Institute for the Semi-Arid Tropics (ICRISAT) in Mali. His PhD (2017 at the University of Ghana) focused on using local Guinea-race sorghum germplasm in breeding for adaptation to low soil-fertility conditions in Mali and West Africa.

Soriba Diakité is a trained agronomist. He currently works as a ValueChain Technical Assistant in Ségou Mali for LuxDev, the Agence Luxembourgeoise pour la Coopération au Développement. He also worked previously for the Novartis Foundation in Ségou, Mali, and other agricultural development agencies and programs. His master's thesis assessing farmers' seed management practices for sorghum in southern Mali proved seminal for initiating joint learning among farmers and breeders for sorghum improvement. His work thus also initiated the collaboration between the Institut Polytechnique Rural, Katibougou, the International Crops Research Institute for the Semi-Arid TropicsMali and the Institut d'Economie Rural for farmer participatory breeding and seed system development.

Alhousseïni Bretaudeau $\mathrm{PhD}$ ) established and heads the Laboratoire d'Agro-physio-génétique et de Biotechnologies Végétales of the Institut Polytechnique Rural de Formation et de Recherche Appliquée IPR/ IFRA, Katibougou, Mali. His vision and emphasis on use of local germplasm for sorghum breeding and on-farm variety testing in the IPR/IFRA student training programs contributed greatly to establishing farmer-participatory plant-breeding research in Mali. His various responsibilities have included Executive Secretary of the Permanent Inter-States Committee for Drought Control in the Sahel (INSAH) (2007-2013), Professor at the University of Bamako, founding member of the Académie des Sciences du Mali, and member of the experts committee Coopéeration pour la Recherche Universitaire et Scientifique (CORUS), France (2003).

Anja Christinck (Dr. agr) is an agronomist specialized in agricultural social sciences and communication. Her scientific work focusses on participatory and transdisciplinary research on agrobiodiversity, plant breeding and seed system development in the context of international development-oriented agricultural research. As an independent researcher and consultant, she contributes to scientific policy advice on issues relating to intellectual property rights for plant varieties and seeds, human rights and rights of farmers. She further contributes to research, teaching and methodology development at the German Institute for Tropical and Subtropical Agriculture (DITSL). 